Monika Peaziak, Anna Irena Szymańska

Uniwersytet Pedagogiczny, Kraków, Polska

\title{
Rola nowoczesnych czynników lokalizacji w procesie decyzyjnym przedsiębiorstw na przykładzie firm sektora budowlanego
}

\author{
The role of modern location factors in enterprises' decision-making \\ processes based on the example of the construction sector
}

Streszczenie: Decyzje dotyczące lokalizacji przedsiębiorstw są złożonym procesem i wymagają wnikliwej analizy wielu czynników. Okazuje się, że czynniki tradycyjne, utożsamiane często z kosztowymi, nie decydują zazwyczaj lub wyłącznie o wyborze lokalizacji przedsiębiorstwa. Wraz z postępem technologicznym i rozwojem społeczeństwa pojawiają się ciągle nowe czynniki, określane mianem nowoczesnych, które towarzyszą powstawaniu nowych działalności gospodarczych będących odpowiedzią na współczesne potrzeby konsumenckie, kreujące nowe produkty i usługi. Z reguły na decyzję lokalizacyjną wpływa szereg czynników zaliczanych zarówno do tradycyjnych (klasycznych), jak też nowoczesnych. W literaturze przedmiotu można spotkać również podział na czynniki „twarde” i „miękkie", czyli wymierne i niewymierne, których udział w procesie decyzyjnym ma różną wagę, a zależy od rodzaju działalności i wielkości przedsiębiorstwa oraz etapu decyzyjnego. W procesie decyzyjnym zazwyczaj istotne znaczenie ma trudno mierzalny czynnik ludzki, odnoszący się do cech i motywów decydenta. Niniejsze opracowanie dotyczy omówienia i identyfikacji istotności współczesnych czynników, ze szczególnym zwróceniem uwagi na aspekt personalny podejmowania decyzji lokalizacyjnych.

Abstract: The decision-making process the enterprises have to go through in order to chose a location
for their business is complex and involves many factors. Apparently, traditional factors which are often
identified with cost-related factors are not the standard, or a sole basis for choosing a location for an
enterprise. New factors continue to emerge, as a result of current technological progress and devel-
opment of society. They are often referred to as modern factors and they accompany the birth of new
businesses which respond to contemporary consumer needs and create new products and services. In
principle, a decision concerning the location of business is influenced by many factors, classified both
as traditional (classical) factors and modern factors. Furthermore, the literature in field offers a distinc-
tion between hard and soft factors i.e. measurable and non-measurable factors, which have a different
importance in a decision-making process. Their impact is dependent on the type of business and a size
of an enterprise and the stage of decision-making. Most commonly the human factor, related to deci-
sion-makers' characteristics and motives, plays an important role in the decision-making process. This
factor is rather difficult to measure. The paper discusses and identifies the importance of the modern 
factors, with a particular emphasis on the personal aspect of the decision-making process in locating enterprises.

Słowa kluczowe: czynniki lokalizacji przedsiębiorstw; klimat inwestycyjny; podejście behawioralne

Keywords: enterprise location factors; investment climate; behavioural approach

\section{WSTĘP}

Wraz z pojawieniem się pierwszych teorii lokalizacyjnych działalności gospodarczej, ogniskujących się najpierw na minimalizacji kosztów (J.H. Tünen 1826, W. Launhardt 1882, A. Weber 1909, A. Predöhl 1925), a później dotyczących analizy rynku i koncentrujących się na maksymalizacji zysków (T. Palander 1935; Lösch, 1940; Hoover, 1948; Isard, 1956), identyfikacja i analiza czynników lokalizacji przedsiębiorstw stała się istotnym problemem badawczym, podejmowanym zarówno przez nauki ekonomiczne, jak również geografię i gospodarkę przestrzenną (Lösch, 1940; Hoover, 1948; Isard, 1956; Fierla, 1998; Wieloński, 2004; Domański, 2011; Płaziak, Szymańska, 2014; Szymańska, Płaziak, 2014). Od samego początku zwrócono szczególną uwagę na fakt, że cechy przestrzeni pośrednio lub bezpośrednio wpływają na decyzję o lokalizacji. Najistotniejszą cechą przestrzeni odgrywającą rolę w podejmowaniu decyzji lokalizacyjnych jest odległość, jako funkcja kosztów transportu surowców i produktów. Geograficzna bliskość (do różnych składowych procesu produkcji i dystrybucji) jest decydującym czynnikiem obniżającym koszty. Szybko zauważono, iż przestrzenna bliskość między przedsiębiorstwami o podobnych działalnościach może przynosić wiele korzyści, tzw. aglomeracyjnych, wynikających głównie z wchodzenia w kooperacje i konfrontacje, ale też z korzystania z powstającej wraz z rozwojem danej branży bazy pracowniczej. Owe korzyści powiązano również ze sferą konsumpcji jako rynku zbytu (Marshall, 1932; Ohlin, 1933; Lösch; 1940, Hoover; 1948). Korzyści aglomeracji były później szczegółowo badane, głównie w aspekcie czynnika tworzenia się klastrów działalności gospodarczej. Wskazywano, iż właśnie bliskość geograficzna, poprzez ułatwienia dotyczące tworzenia więzi między podmiotami gospodarczymi i powstawania sieci działalności, bezpośrednio wpływa na kreowanie klastrów (Krugman, 1991; McCann, 2001; Karlsson, Johansson, Strough, 2005).

Analizy czynników i modyfikacje pierwszych teorii lokalizacyjnych, zakładających spore uproszczenia, szybko ujawniły, iż niemożliwym jest stworzenie uniwersalnego zbioru czynników wpływających na decyzję o lokalizacji przedsiębiorstwa. Z czasem do badań włączano czynniki dotychczas niebrane pod uwagę, jak też uwzględniano całkowicie nowe, pojawiające się wraz z rozwojem technologicznym, często towarzyszące nowym formom działalności gospodarczej. Czynniki związane z bliskością bazy surowcowej, rynków zbytu, dostępu do nieruchomości, bazy transportowej, siły roboczej (w sensie kosztów pracy) uważa się w literaturze przedmiotu za czynniki tradycyjne (klasyczne), odgrywające rolę decydujących czynników lokalizacyjnych jeszcze w latach 60. XX wieku. Obecnie, zwłaszcza w niektórych branżach, mają one nadal spory udział w decyzjach lokalizacyjnych, jednakże 
coraz większego znaczenia nabierają czynniki jakościowe, odnoszące się nie tyle do dostępności siły roboczej, co do jej kwalifikacji, a także szeroko rozumianego odpowiedniego klimatu biznesowego danego regionu dla firm (Wach, 2008). Znaczenia nabierają nie tylko czynniki przyciągające przedsiębiorcę, ale również te, które są atrakcyjne dla pracowników, szczególnie należących do grupy wysokich specjalistów, dla których potencjalny wysoki poziom życia czy szerzej rozumiana - pod względem rozpiętości zaspokojenia potrzeb wyższego rzędu - jakość życia stanowić może decydujący czynnik wyboru miejsca zamieszkania, a więc i pracy. Analizom poddawane są coraz częściej także subiektywne aspekty wyboru lokalizacji z pozycji przedsiębiorcy (podejście behawioralne).

Niniejsze opracowanie zawiera prezentację i omówienie wyników badań dotyczących nowoczesnych czynników lokalizacyjnych, wynikających z postępu technologicznego i rozwoju społecznego. Jest kontynuacją opracowania dotyczącego wcześniejszego etapu badań, skupiającego się na czynnikach lokalizacji tradycyjnych (klasycznych). Analizie poddano przedsiębiorstwa sektora budowlanego, który uważany jest powszechnie za dziedzinę działalności gospodarczej szybko reagującą na zmiany w tendencjach rozwoju gospodarki.

Celem artykułu było określenie istotności wybranych nowoczesnych czynników lokalizacji przedsiębiorstw w procesie decyzyjnym przedsiębiorców w odniesieniu do miejsca usytuowania działalności gospodarczej omawianego sektora na terenie województwa małopolskiego. Postawiono następujące tezy badawcze: 1) zarówno tradycyjne, jak i nowoczesne czynniki lokalizacji pozostają istotne w procesie decyzyjnym, jednak ich struktura ważności zależna jest od charakteru prowadzonej działalności gospodarczej, również w ramach sektora budowlanego - w rozróżnieniu na firmy stricte budowlane, jak i biura architektoniczne; 2) szczególnie istotnym czynnikiem w procesie decyzyjnym jest czynnik personalny, który ma związek z wyborem zadowalającej lokalizacji.

W celu weryfikacji postawionych tez zastosowano takie narzędzia badawcze, jak: krytyka piśmiennictwa, badania pilotażowe, kwestionariusz kierowany, studium przypadku.

\section{WSPÓŁCZESNE CZYNNIKI LOKALIZACJI PRZEDSIĘBIORSTW - ZAGADNIENIA TEORETYCZNE}

Jak podkreślono we wstępie, aktualnie na znaczeniu lokalizacyjnym przedsiębiorstw przybiera rola czynników związanych z postępem gospodarczym, a co za tym idzie, z rozwojem technologicznym i społecznym. Wiele spośród tych czynników pojawiło się dopiero wraz z wdrożeniem nowych technologii, zwłaszcza informacyjnych, oraz pojawieniem się nowych potrzeb konsumentów i pracowników. Z całą pewnością do nowoczesnych czynników możemy zaliczyć: jakość kapitału ludzkiego i społecznego, dostęp do informacji, kapitał wiedzy i kreatywności, usługi biznesowe oraz walory otoczenia, na które obok środowiska przyrodniczego składają się klimat społeczny i polityka władz lokalnych (Domański, 2011).

Kapitał ludzki oznacza współcześnie nie tyle dostęp do taniej siły roboczej, zwłaszcza w przypadku przedsiębiorstw z zakresu produkcji wysokiej technologii i usług wyższego 
rzędu, co możliwość pozyskania pracowników wysoko wykwalifikowanych, elastycznych i ciągle uczących się. Z pewnością na kwalifikacje kadry pracowniczej wywiera wpływ ogólny poziom rozwoju społeczno-gospodarczego regionu, który przekłada się na określone możliwości zdobycia wykształcenia oraz kwalifikacji i doświadczenia zawodowego (Fierla, 1998).

Kapitał społeczny, wyrażający się poprzez skłonność jednostek do łączenia wysiłków w celu zaspokojenia swoich potrzeb, wzajemnej pomocy i ochrony wspólnego dobra, tworzony w procesie budowy społeczeństwa obywatelskiego jest istotnym walorem lokalizacyjnym działalności gospodarczej, stanowiącym wraz z kapitałem ludzkim istotny element składowy klimatu społecznego danego miejsca lub regionu. Kapitał społeczny jest określany jako sytuacja na rynku pracy oraz uwarunkowania społeczno-ekonomiczne wpływające na jakość pracy (m.in. wykształcenie i struktura wieku potencjalnej siły roboczej) i stosunek do pracy, nastawienie społeczeństwa do przemian rynkowych (Budner, 2003).

Obok klimatu społecznego, na klimat inwestycyjny miejsca bądź regionu składa się szereg innych czynników, zwłaszcza dwojakiego rodzaju klimat ekonomiczny. Pierwszy rodzaj klimatu ekonomicznego dotyczy aktualnej i przewidywanej sytuacji gospodarczej kraju, czyli stabilności gospodarczej oraz wielkości i chłonności rynku zbytu, co uznać możemy nie tyle za czynnik lokalizacyjny przedsiębiorstwa, co raczej za uwarunkowania determinujące samo podjęcie decyzji o dokonaniu inwestycji. Drugi rodzaj klimatu ekonomicznego tworzony jest przez stan instytucji i urządzeń składających się na infrastrukturę gospodarki rynkowej, istotnej dla prowadzenia działalności gospodarczej na poziomie regionalnym i lokalnym. Chodzi tutaj zwłaszcza o infrastrukturę techniczną oraz infrastrukturę otoczenia biznesu, czyli różnorodne instytucje i organizacje społeczne oraz gospodarcze, których działalność przyczynia się do rozwoju przedsiębiorczości i usprawniania procesów wymiany towarów i usług. Do infrastruktury otoczenia biznesu zalicza się najczęściej: banki i instytucje ubezpieczeniowe, towarzystwa i izby gospodarcze, agencje i fundacje rozwoju lokalnego oraz regionalnego, ośrodki innowacji i przedsiębiorczości, instytucje doradcze, punkty informacyjne, centra szkoleniowe, instytucje promocyjno-handlowe, giełdy, domy maklerskie, a w warunkach polskich również specjalne strefy ekonomiczne.

Na klimat inwestycyjny składają się także klimaty: polityczny, administracyjny i prawny. Klimat polityczny, podobnie jak pierwszy z dwóch rodzajów opisanego wyżej klimatu ekonomicznego, dotyczy raczej ogólnych uwarunkowań kraju lub regionu, tym razem pod względem sytuacji politycznej, którą tworzą: stabilność polityczna, poglądy polityków rządzących i urzędników rządowych, partykularne dążenia kół rządzących, znaczenie sektora prywatnego w gospodarce, przywileje dla przedsiębiorców krajowych lub zagranicznych oraz uwarunkowania historyczne. Natomiast klimat administracyjny tworzony jest przez zasięg wpływu administracji na następujące działania decyzyjne i lokalizacyjne dotyczące przedsiębiorstw: zakres działalności, procedura zakładania firmy, przepisy regulujące transfer zysku, szybkość i elastyczność działania administracji. Klimat prawny tworzą natomiast przepisy i regulacje prawne, a w szczególności stabilne, przejrzyste i ujednolicone rozwiązania prawne, gwarancja własności, możliwość transferu zysków.

Wydaje się zasadne, aby do klimatu inwestycyjnego zaliczyć również walory przyrodnicze i kulturowe otoczenia, które będą wpływać pozytywnie na ocenę miejsca lub regionu 
z punktu widzenia poziomu i jakości życia przedsiębiorców i potencjalnych pracowników, jako coraz częściej rozpatrywany aspekt lokalizacji przedsiębiorstw.

W literaturze przedmiotu klimat inwestycyjny utożsamiany jest z klimatem biznesu, choć czasami pojmowany jest nieco węziej, jako zawierający część składowych klimatu inwestycyjnego: klimat ekonomiczny drugiego rodzaju wraz z klimatem społecznym i administracyjnym. Uogólniając, można stwierdzić, iż czynniki lokalizacji tworzą określony klimat inwestycyjny (lub klimat biznesu), oceniany z punktu widzenia inwestora (Budner, 2003).

Aktualnie szczególnego znaczenia w aspekcie czynników lokalizacyjnych nabiera dostęp do informacji. Przepływ informacji jest nierozerwalnie związany z rozwojem współczesnej gospodarki i społeczeństwa, które możemy określić mianem informacyjnego. Współcześnie środowisko przedsiębiorstw i ich cele zmieniają się bardzo szybko, a to wymaga napływu ciągle nowych informacji. Jeżeli przyjmiemy za G.E. Törnqvistem (Törnqvist, 1977) podział komunikacji w gospodarce na trzy płaszczyzny: 1) transport dóbr, 2) komunikacja osobista face to face i 3) telekomunikacja, przy czym ta trzecia jest odnoszona obecnie głównie do internetu, to należy stwierdzić, że dwie ostatnie płaszczyzny, a zwłaszcza trzecia, stanowią, w wielu przypadkach, jeśli nie najistotniejszy, to przynajmniej równie ważny co transport dóbr czynnik lokalizacyjny (Walmsley, Lewis, 1984). Skąpy zakres informacji, jak też problemy z wykorzystaniem posiadanych informacji, mogą wpływać na utrudnienia prawidłowego wyboru lokalizacji. Ponadto należy liczyć się z faktem, iż koszt uzyskania informacji może okazać się wysoki. I nie chodzi tutaj o dostęp do informacji, gdyż w dobie internetu koszty dostępu informacyjnego zostały znacznie obniżone, ale oczywiście należy uwzględnić koszty związane z dostępem do płatnych baz danych. Chodzi raczej o koszty zdobycia i przetwarzania informacji wynikające z konieczności zatrudniania wykwalifikowanych w tym zakresie specjalistów, którzy są dobrze opłacani, a więc i kosztowni z punktu widzenia przedsiębiorcy.

Z opisanymi wcześniej kapitałem ludzkim i społecznym oraz rolą dostępu i przepływu informacji wiążą się ściśle kapitał wiedzy i kreatywności, będące nowoczesnymi czynnikami odgrywającymi istotną rolę w decyzjach lokalizacyjnych działalności gospodarczej. Wiedzę i kreatywność możemy w tym względzie traktować jako część infrastruktury gospodarczej i gry rynkowej. Wiedza, zwłaszcza techniczna i specjalistyczna, determinuje ewolucję gospodarki, w związku z pojawianiem się punktów zwrotnych i zasadniczych zmian w jej strukturze. Wiedza i kreatywność skupiają się głównie w dużych aglomeracjach miejsko-przemysłowych i węzłach kontaktów gospodarczych, organizacyjnych, technicznych i naukowych, wskutek czego są czynnikami dopełniającymi korzyści aglomeracji i przyczyniającymi się do polaryzacji gospodarki w przestrzeni (Rachwał, 2012; Domański, 2011).

Nie można rozpatrywać czynników lokalizacji przedsiębiorstw, nie uwzględniając jednej z niezwykle istotnych składowych, jaką stanowi czynnik personalny. W literaturze przedmiotu traktującej o problematyce decyzyjnej lokalizacji przedsiębiorstw od połowy XX wieku spotkać się można z podejściem behawioralnym. Uwzględnia ono zarówno ujawnione zachowania przestrzenne explicit spatial behaviours, np. utworzenie nowego zakładu przemysłowego, jak i domniemane zachowania przestrzenne implicit spatial behaviours, np. zmianę skali istniejącego zakładu (Hamilton, 1978, za: Walmsley, Lewis, 1984). 
Jednym z pierwszych krytyków normatywnych teorii lokalizacyjnych był A.R. Pred (Pred, 1967), który uważał te teorie za logicznie niespójne, gdy traktuje się je w charakterze uzasadnienia całości komponentów decyzyjnych. Zakwestionował on istnienie tzw. człowieka racjonalnego, homo oeconomicus, decydującego zgodnie z zasadami ekonomii i w pełni poinformowanego o problemach, jakie napotyka, oraz o konsekwencjach swoich działań i wyborów. Podejście behawioralne uwzględnia w tłumaczeniu procedury lokalizacyjnej istnienie osoby decydenta, którego zachowanie charakteryzuje ograniczona racjonalność bounded rationality. Nie jest on zdolny do zebrania i wykorzystania kompletnego pakietu informacji dotyczących chociażby sytuacji rynkowej, możliwości kapitałowych czy dostępu do technologii. Takie podejście przyjmuje założenie tzw. zachowania zadowalającego satisficing behaviour decydenta, akcentując czynniki pozaekonomiczne w procesie decyzyjnym wyboru lokalizacji przedsiębiorstwa. W praktyce homo satisfaciendus szuka lokalizacji zadowalających, nie osiągając w rezultacie lokalizacji optymalnych (Hurst, 1974, za: Wieloński, 2004).

Decyzje zadowalające zostają podejmowane z wielu powodów. Po pierwsze, o czym już wspomniano, wynikają z braku dostępu do kompletnych informacji oraz możliwości ich pełnej interpretacji. Po drugie, istotną rolę odgrywają czynniki personalne, wielowymiarowe. I tak, wiele decyzji podejmowanych może być w związku ze szczególnie dobrą znajomością danego miejsca lub regionu, wynikającą z faktu urodzenia się tam decydenta bądź jego zamieszkania tam. Ponadto niebagatelną rolę odgrywa ludzka percepcja przestrzeni, zależna od wielu zmiennych, chociażby wieku, doświadczenia, wykształcenia, aspiracji, uprzedzeń (ta sama przestrzeń jest odmienna dla różnych osób). Należy zwrócić także uwagę na istnienie tzw. efektu imitacji (Pred, 1967), który dotyczy skłonności decydentów do powtarzania decyzji własnych lub konkurentów. Innym istotnym zachowaniem towarzyszącym podejmowaniu decyzji zadowalających jest inklinacja do unikania trudności, np. uchylanie się od zawiłych negocjacji ze związkami zawodowymi lub innymi grupami czy instytucjami.

Proces decyzyjny lokalizacji działalności gospodarczej charakteryzuje mnogość i złożoność czynników. W literaturze przedmiotu można spotkać się z podziałem czynników lokalizacyjnych na grupe „twardych” i „miękkich”. Przy czym czynniki „twarde” odpowiadają najczęściej czynnikom wymiernym (kosztowym), w pewnym zakresie tradycyjnym (klasycznym). Zaliczymy do tej grupy chociażby takie składowe, jak: podaż powierzchni produkcyjnych i biurowych, bliskość zbytu w regionie, bliskość dostawców i kooperantów, odpowiednie połączenia komunikacyjne, ale także podaż wykwalifikowanej siły roboczej, sprzyjającą wysokość podatków, zachęty i subwencje, występowanie instytutów naukowych i badawczych dających możliwości kooperacji, istnienie ośrodków szkolenia zawodowego, szybko działającą i elastyczną administrację. Do czynników „miękkich” zaliczymy niewymierne, często subiektywne aspekty decyzyjne, jak np.: przychylne nastawienie władz samorządowych do inwestora, gospodarczy wizerunek miejsca lokalizacji, mentalność mieszkańców, klimat społeczny, możliwości spędzania wolnego czasu, wieloaspektowa aktywność miasta, warunki mieszkaniowe, jakość szkół, oferta kulturalna czy szerzej - poziom i jakość życia (Grabow, Henckel, Hollbach-Grömig, 1995, za: Dziemianowicz, 1997). 
W postępowaniu decyzyjnym dotyczącym lokalizacji działalności gospodarczej obie grupy powyżej opisanych czynników odgrywają znaczącą rolę. Jednakże ich waga jest różna i zależy zazwyczaj od rodzaju działalności oraz etapu procesu decyzyjnego. W pierwszej fazie tego procesu, kiedy następuje wyznaczenie regionu lokalizacji, dużą rolę mogą odgrywaćczynniki „miękkie”, takie jak wiedza inwestora o regionie czy doświadczenie innych firm w tym regionie. Nie oznacza to oczywiście, że wybór regionu następuje czysto intuicyjnie. Prowadzone są jednocześnie analizy popytu regionalnego oraz porównawcze analizy nakładów i wyników w poszczególnych regionach. W drugiej fazie procesu decyzyjnego, prowadzącej do wyboru skończonej liczby potencjalnych miejsc lokalizacji, charakteryzujących się najniższymi kosztami produkcji lub świadczenia usług, znaczenie czynników „miękkich” ustępuje ważnością czynnikom „twardym”, które określają wymierne korzyści ekonomiczne ewentualnej lokalizacji. W ostatniej, trzeciej fazie postępowania decyzyjnego, w sytuacji gdy zostało wyłonionych kilka miejsc potencjalnie odpowiednich, o zbliżonych kosztach, czynniki „miękkie” ponownie mogą nabrać znaczenia. Przykładowo, o ostatecznej lokalizacji (wyborze jednej spośród kilku opcji) zadecydować może niekoniecznie nieco niższa cena gruntów czy korzystniejsze położenie komunikacyjne, ale bardziej sprzyjający klimat społeczny lub wyższe kompetencje i operatywność urzędników albo walory wypoczynkowe danego miejsca (Budner, 2003).

Podsumowując powyższe rozważania teoretyczne, autorki konstatują, iż w procesie decyzyjnym dotyczącym lokalizacji działalności gospodarczej istnieje złożoność czynników wpływających na decyzję finalną. Różna jest ponadto waga poszczególnych czynników, zależna od rodzaju działalności, wielkości przedsięwzięcia, etapu procesu decyzyjnego. Czynników tych nie można rozpatrywać bez jednego istotnego, jakim jest czynnik personalny. Decyzję podejmuje przedsiębiorca (decydent), z całym swoim bagażem cech ludzkich i doświadczeń, wraz z osobistymi zamierzeniami (ryc. 1).

\begin{tabular}{|c|c|}
\hline $\begin{array}{c}\text { Działalność } \\
\text { gospodarcza } \\
\text { (lokalizacja) }\end{array}$ & $=\begin{array}{c}\text { Człowiek } \\
\text { (decydent) }\end{array}$
\end{tabular}$+\begin{gathered}\text { Wymagania } \\
\text { inwestycyjne }\end{gathered}+\begin{gathered}\text { Klimat } \\
\text { inwestycyjny }\end{gathered}$

Ryc. 1. Elementy decyzyjne podjęcia działalności gospodarczej

Źródło: opracowanie własne

W wielu pracach odnoszących się do poruszanej problematyki sporo uwagi poświęca się ograniczeniom (barierom) lokalizacyjnym działalności gospodarczej. Klasyfikuje się je różnie, m.in. w zależności od rodzaju, wielkości i wpływu na lokalizację. Autorki przyjęły założenie, że bariera lokalizacyjna to nic innego, jak brak występowania czynnika lokalizacyjnego, ewentualnie jego niedostateczność lub wyczerpanie (Fierla, 1987; Budner, 2003), stąd nie uwzględniono w tym opracowaniu osobnego omówienia problematyki barier w decyzjach lokalizacyjnych przedsiębiorstw. 
ANALIZA WSPÓŁCZESNYCH CZYNNIKÓW LOKALIZACJI PRZEDSIĘBIORSTW NA PRZYKŁADZIE WYBRANYCH FIRM BUDOWLANYCH I ARCHITEKTONICZNYCH

W toku postępowania badawczego dokonano empirycznej analizy istotności współczesnych czynników lokalizacji przedsiębiorstw. W tym celu przeprowadzono marketingowe badania bezpośrednie wśród właścicieli firm architektonicznych i budowlanych z województwa małopolskiego. W badaniach zastosowano metody bezpośredniego wywiadu kwestionariuszowego oraz wywiadu pogłębionego. Wykorzystano dwa wzory kwestionariusza wywiadu: 1) kwestionariusz A, z pytaniami dotyczącymi znaczenia klasycznych czynników lokalizacji przedsiębiorstw, 2) kwestionariusz B, z pytaniami dotyczącymi znaczenia nowoczesnych czynników lokalizacji przedsiębiorstw.

W każdym z kwestionariuszy przedstawiono respondentom (właścicielom przedsiębiorstw) wykaz czynników lokalizacji, przy czym kwestionariusz A zawierał 31 pytań, uporządkowanych w sześciu grupach, natomiast kwestionariusz B zawierał 38 pytań, uporządkowanych w siedmiu grupach. Zadaniem respondentów było dokonanie oceny wpływu poszczególnych czynników na decyzje, jakie podjęli w odniesieniu do lokalizacji swojego przedsiębiorstwa. W pierwszej kolejności ocenie poddano poszczególne grupy czynników jako pewne całości, dlatego nazwano je czynnikami bazowymi. Następnie ocenie podlegały czynniki cząstkowe poszczególnych grup (czynników bazowych). Należy zaznaczyć, iż istniała dla respondentów możliwość podania czynników innych niż zaproponowane w kwestionariuszu, uważanych przez nich za istotne.

Proces gromadzenia informacji był czterofazowy. Pierwsza faza obejmowała badanie pilotażowe, dotyczące dwóch przedsiębiorstw, służące sprawdzeniu poprawności konstrukcji kwestionariusza wywiadu. W fazach drugiej i trzeciej przeprowadzono badania z wykorzystaniem kwestionariusza wywiadu w grupie 53 przedsiębiorców reprezentujących sektor budowlany (firmy budowlane i architektoniczne). Respondenci reprezentowali firmy zróżnicowane pod względem wielkości: przedsiębiorstwa mikro (8 firm), małe (3) i średnie (2) ${ }^{1}$. Wszystkie przedsiębiorstwa zlokalizowane były w województwie małopolskim.

Ostatnia, czwarta faza procesu gromadzenia informacji polegała na przeprowadzeniu wywiadu pogłębionego z właścicielami dwóch wybranych przedsiębiorstw i dotyczyła określenia znaczenia subiektywnych (personalnych) czynników lokalizacji. Ostatecznie, pełnych informacji spośród 53 badanych przedsiębiorstw udzieliło 13 właścicieli i ta grupa została zakwalifikowana do dalszej analizy. Fakt ten spowodowany był wysokim poziomem skomplikowania kwestionariuszy i niechęcią przedsiębiorców do udziału w tego rodzaju badaniach. W związku z powyższym wyniki analizy mają charakter poglądowy i stanowią wstęp do dalszych badań wśród większej grupy przedsiębiorstw.

W niniejszym opracowaniu przedstawiono wyniki dotyczące danych zebranych za pomocą kwestionariusza B, czyli dotyczących istotności nowoczesnych czynników lokalizacji

${ }^{1}$ Klasyfikacja przedsiębiorstw dokonana ze względu na ich wielkość, czyli liczbę zatrudnianych pracowników. Mikroprzedsiębiorstwa zatrudniają do dziewięciu pracowników, małe przedsiębiorstwa od 10 do 49 pracowników, natomiast średnie przedsiębiorstwa od 50 do 249 pracowników. 
przedsiębiorstw. Ponadto zaprezentowano wnioski będące efektem przeprowadzenia wywiadu pogłębionego z właścicielami jednego spośród dwóch przedsiębiorstw, z którymi takie wywiady zostały zrealizowane.

Poniżej znajduje się lista nowoczesnych czynników lokalizacji, które zawierał kwestionariusz B (tab. 1). Czynniki zostały uporządkowane w siedmiu następujących grupach: 1) infrastruktura informacyjno-telekomunikacyjna, 2) rynek kapitałowy, 3) instytucje wsparcia biznesu, 4) baza akademicka, szkolnictwa zawodowego i jednostek badawczo-rozwojowych, 5) klimat gospodarczy, 6) tradycje historyczno-kulturowe, 7) poziom i jakość życia. Doboru nowoczesnych czynników dokonano w oparciu o literaturę przedmiotu, uwzględniając czynniki najczęściej w niej wymieniane w aspekcie współczesności i nowoczesności.

Tab. 1. Nowoczesne czynniki lokalizacji i ocena ich istotności dokonana przez właścicieli przedsiębiorstw

\begin{tabular}{|c|c|c|c|}
\hline Lp. & Grupa czynników & Czynniki & Średnia ocena \\
\hline \multirow[t]{8}{*}{1.} & \multirow{8}{*}{$\begin{array}{l}\text { Infrastruktura } \\
\text { informacyjno- } \\
\text { telekomunikacyjna }\end{array}$} & Dostępność sieci telefonii stacjonarnej & 4,00 \\
\hline & & Dostępność sieci telefonii mobilnej (komórkowej) & 4,23 \\
\hline & & Dostępność internetu szerokopasmowego & 4,08 \\
\hline & & $\begin{array}{l}\text { Dostęp do punktów bezprzewodowego internetu } \\
\text { (hot spot) }\end{array}$ & 2,77 \\
\hline & & $\begin{array}{l}\text { Dostęp do ośrodków call center (ośrodków obsługi } \\
\text { klienta, wsparcia serwisowego) }\end{array}$ & 2,69 \\
\hline & & Dostęp do elektronicznych usług medycznych (e-health) & 2,77 \\
\hline & & $\begin{array}{l}\text { Dostęp do elektronicznych usług administracyjnych } \\
\text { (e-government) }\end{array}$ & 3,15 \\
\hline & & Dostęp do elektronicznej edukacji (e-learning) & 3,00 \\
\hline \multirow[t]{4}{*}{2.} & \multirow[t]{4}{*}{ Rynek kapitałowy } & Dostępność instytucji finansowych & 2,92 \\
\hline & & Dostęp do kapitału obcego (pożyczki, kredyty itp.) & 2,85 \\
\hline & & $\begin{array}{l}\text { Dostęp do finansowego wsparcia ze strony programów } \\
\text { regionalnych (poręczenia, granty, dotacje itd.) }\end{array}$ & 3,54 \\
\hline & & $\begin{array}{l}\text { Stosowane ulgi podatkowe, przyspieszona amortyzacja } \\
\text { wydatków inwestycyjnych itp. }\end{array}$ & 4,08 \\
\hline \multirow[t]{4}{*}{3.} & \multirow{4}{*}{$\begin{array}{l}\text { Instytucje wsparcia } \\
\text { biznesu }\end{array}$} & Dobrze rozwinięta sieć instytucji wsparcia biznesu & 3,46 \\
\hline & & Dobrze rozwinięta sieć usług szkoleniowych & 3,23 \\
\hline & & $\begin{array}{l}\text { Dobrze rozwinięta sieć usług doradczo-konsul- } \\
\text { tingowych }\end{array}$ & 2,85 \\
\hline & & $\begin{array}{l}\text { Dobrze rozwinięta sieć usług z zakresu transferu } \\
\text { technologii }\end{array}$ & 3,08 \\
\hline
\end{tabular}




\begin{tabular}{|c|c|c|c|}
\hline \multirow[t]{5}{*}{4.} & \multirow{5}{*}{$\begin{array}{l}\text { Baza akademicka, } \\
\text { szkolnictwa } \\
\text { zawodowego } \\
\text { i jednostek } \\
\text { badawczo- } \\
\text {-rozwojowych }\end{array}$} & Bliskość szkół wyższych & 2,85 \\
\hline & & Bliskość szkół zawodowych & 2,54 \\
\hline & & Oferta edukacyjna adekwatna do potrzeb rynku pracy & 3,15 \\
\hline & & Możliwość dalszego kształcenia pracowników & 3,15 \\
\hline & & $\begin{array}{l}\text { Możliwość realizacji wspólnych projektów } \\
\text { z jednostkami badawczo-rozwojowymi }\end{array}$ & 3,15 \\
\hline \multirow[t]{9}{*}{5.} & \multirow{9}{*}{$\begin{array}{l}\text { Klimat } \\
\text { gospodarczy }\end{array}$} & Zrozumiałe i spójne procedury administracyjne & 4,38 \\
\hline & & Wysoki poziom kwalifikacji urzędników & 4,31 \\
\hline & & Szybkie wydawanie decyzji administracyjnych & 4,46 \\
\hline & & $\begin{array}{l}\text { Łatwy dostęp do informacji o obowiązujących } \\
\text { przepisach prawnych (podatkowych itp.) }\end{array}$ & 3,85 \\
\hline & & $\begin{array}{l}\text { Spójność interpretacji prawnych i decyzji } \\
\text { administracyjnych }\end{array}$ & 4,15 \\
\hline & & $\begin{array}{l}\text { Pozytywne nastawienie władz lokalnych do } \\
\text { przedsiębiorców }\end{array}$ & 4,54 \\
\hline & & $\begin{array}{l}\text { Działania władz lokalnych mające na celu promocję } \\
\text { regionalnych przedsiębiorstw }\end{array}$ & 3,85 \\
\hline & & $\begin{array}{l}\text { Otwartość władz lokalnych na indywidualne potrzeby } \\
\text { przedsiębiorców }\end{array}$ & 4,00 \\
\hline & & Jasna wizja kierunków rozwoju regionu & 4,00 \\
\hline \multirow[t]{3}{*}{6.} & \multirow{3}{*}{$\begin{array}{l}\text { Tradycje } \\
\text { historyczno- } \\
\text {-kulturowe }\end{array}$} & $\begin{array}{l}\text { Tradycje funkcjonowania branży budowlanej na danym } \\
\text { terenie }\end{array}$ & 3,38 \\
\hline & & Otwartość społeczności lokalnej wobec inwestorów & 3,77 \\
\hline & & $\begin{array}{l}\text { Lokalna etyka biznesowa (wartości i normy } \\
\text { funkcjonujące w lokalnej gospodarce) }\end{array}$ & 4,23 \\
\hline \multirow[t]{5}{*}{7.} & \multirow{5}{*}{$\begin{array}{l}\text { Poziom i jakość } \\
\text { życia }\end{array}$} & Atrakcyjny wizerunek gminy lub miasta & 3,77 \\
\hline & & Poziom bezpieczeństwa na danym obszarze & 3,77 \\
\hline & & $\begin{array}{l}\text { Oferta kulturalna i rekreacyjna (kina, teatry, galerie, } \\
\text { kluby sportowe, ścieżki rowerowe itp.) }\end{array}$ & 2,92 \\
\hline & & Koszty utrzymania & 4,38 \\
\hline & & Koszty wynajmu lub zakupu mieszkań & 4,46 \\
\hline
\end{tabular}

Źródło: opracowanie własne na podstawie: Tobolska, 2011; Fabińska, Piasecki, 2007; Wieloński, 2004; Dziemianowicz 1997

Spośród siedmiu czynników bazowych za najistotniejszy został przez respondentów uznany klimat gospodarczy (4,23 pkt). W następnej kolejności były to następujące czynniki: infrastruktura informacyjno-telekomunikacyjna $(3,77)$, instytucje wsparcia biznesu $(3,69)$ oraz poziom i jakość życia $(3,69)$. Kolejne zostały uznane za zdecydowanie mniej istotne, były to: tradycje historyczno-kulturowe $(2,92)$ oraz rynek kapitałowy $(2,69)$ i baza akademicka, szkolnictwa zawodowego i jednostek badawczo-rozwojowych $(2,69)$ (ryc. 2). 


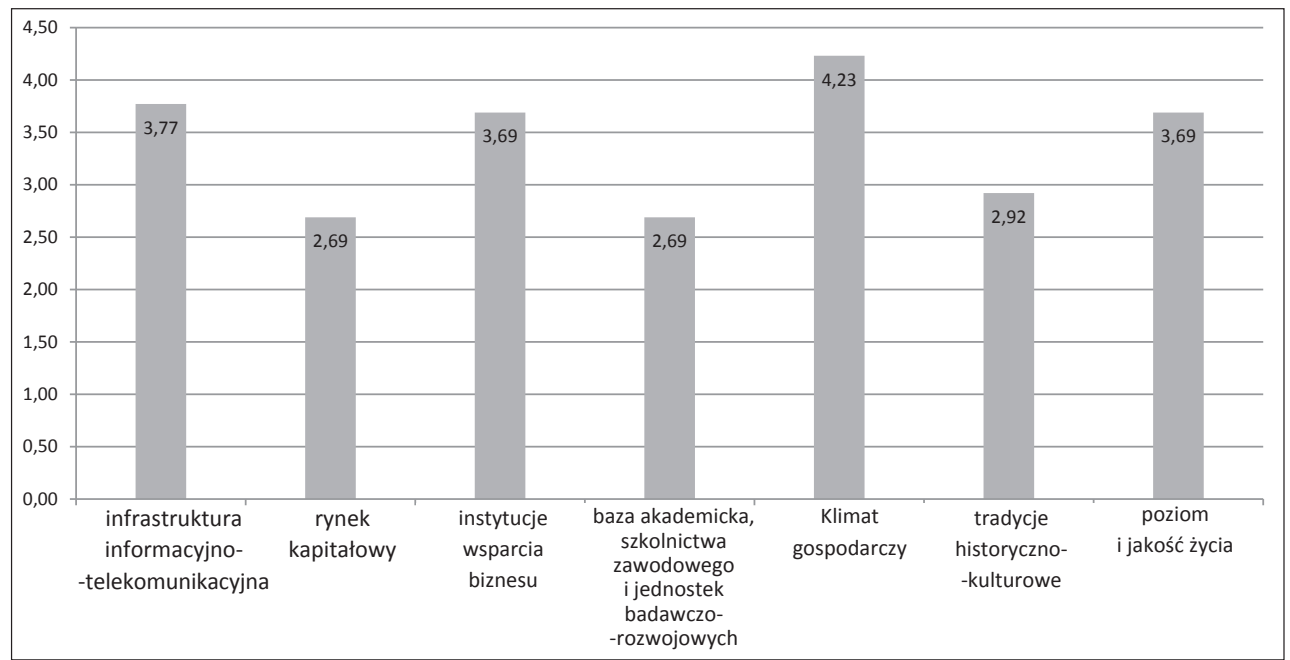

Ryc. 2. Istotność nowoczesnych czynników bazowych lokalizacji w ocenie właścicieli przedsiębiorstw uczestniczących w badaniach

Źródło: opracowanie własne w oparciu o wyniki badań ankietowych

W drugim etapie badań $\mathrm{z}$ wykorzystaniem kwestionariusza $\mathrm{B}$ analizie poddano ocenę poszczególnych czynników cząstkowych. W grupie czynników dotyczących infrastruktury informacyjno-telekomunikacyjnej za najistotniejszy został przez respondentów uznany czynnik dostępność do sieci mobilnej (komórkowej) (4,23 pkt). W grupie dotyczącej rynku kapitałowego zdecydowanie najważniejszy okazał się czynnik stosowane ulgi podatkowe i przyspieszona amortyzacja wydatków inwestycyjnych $(4,08)$. W grupie odnoszącej się do instytucji wsparcia biznesu za najistotniejszy został uznany czynnik dobrze rozwinięta sieć instytucji wsparcia biznesu $(3,46)$. W grupie czynników związanych z bazą akademicką, szkolnictwem zawodowym i jednostkami badawczo-rozwojowymi za jednakowo wysoko ważne uznano trzy czynniki: oferta edukacyjna adekwatna do potrzeb rynku pracy $(3,15)$, możliwość dalszego kształcenia pracowników $(3,15)$, możliwość realizacji wspólnych projektów z jednostkami badawczo-rozwojowymi $(3,15)$. W grupie czynników odnoszących się do klimatu gospodarczego najwyższą ocenę uzyskał czynnik pozytywne nastawienie władz lokalnych do przedsiębiorców $(4,54)$. Wśród czynników nawiązujących do tradycji historyczno-kulturowych największe znaczenie miał czynnik lokalna etyka biznesowa (wartości i normy funkcjonujące w lokalnej gospodarce) $(4,23)$. W grupie odwołującej się do poziomu i jakości życia zdecydowanie dominował czynnik koszty wynajmu lub zakupu mieszkań $(4,46)$ (tab. 1).

Biorąc pod uwagę zbiór wszystkich czynników, za najważniejsze (ocenione powyżej 4,00 pkt) pod względem lokalizacji uznano następujące spośród nich, począwszy od najważniejszych: pozytywne nastawienie władz lokalnych do przedsiębiorców, szybkie wydawanie decyzji administracyjnych, koszty wynajmu lub zakupu mieszkań, zrozumiałe i spójne procedury administracyjne, koszty utrzymania, wysoki poziom kwalifikacji urzędników, dostępność sieci telefonii mobilnej (komórkowej), lokalna etyka biznesowa (wartości i normy 
funkcjonujące w lokalnej gospodarce), spójność interpretacji prawnych i decyzji administracyjnych, dostępność internetu szerokopasmowego, stosowane ulgi podatkowe, przyspieszona amortyzacja wydatków inwestycyjnych itp. Natomiast najniżej (poniżej 3,00 pkt) ocenione zostały następujące czynniki: dostępność instytucji finansowych, oferta kulturalna i rekreacyjna (kina, teatry, galerie, kluby sportowe, ścieżki rowerowe itp.), dostęp do kapitału obcego (pożyczki, kredyty, itp.), dobrze rozwinięta sieć usług doradczo-konsultingowych, bliskość szkół wyższych, dostęp do punktów bezprzewodowego Internetu (hot spot), dostęp do elektronicznych usług medycznych (e-health), dostęp do ośrodków call center (ośrodków obsługi klienta, wsparcia serwisowego), bliskość szkół zawodowych (tab. 1).

W toku dalszej analizy, uwzględniając charakter prowadzonej przez badane przedsiębiorstwa działalności, podzielono je na dwie grupy: firmy architektoniczne (5) i firmy budowlane (8). Następnie obliczono wagę ocen uzyskanych dla wszystkich czynników należących do danej grupy w stosunku do maksymalnie możliwej do uzyskania oceny w tej grupie (tab. 2). Wagę wyliczono jako udział procentowy sumy uzyskanych ocen w stosunku do maksymalnej możliwej sumy ocen (,,5” pomnożone przez liczbę czynników w danej grupie). Wyliczone wagi pozwoliły na wykonanie profili lokalizacyjnych dla firm architektonicznych i budowlanych (ryc. 3).

Tab. 2. Ocena istotności poszczególnych grup nowoczesnych czynników lokalizacji $\mathrm{z}$ uwzględnieniem podziału na firmy architektoniczne i budowlane

\begin{tabular}{|c|l|c|c|c|c|c|c|}
\hline \multirow{2}{*}{ Lp. } & \multicolumn{1}{|c|}{$\begin{array}{c}\text { Grupy nowoczesnych } \\
\text { czynników lokalizacji }\end{array}$} & $\begin{array}{c}|c| \\
\text { Sirmy architektoniczne }\end{array}$ & \multicolumn{3}{c|}{ Firmy budowlane } \\
\cline { 3 - 8 } & & $\begin{array}{c}\text { Ścena } \\
\text { w pkt }\end{array}$ & $\begin{array}{c}\text { Sumaryczna } \\
\text { ocena w \% }\end{array}$ & $\begin{array}{c}\text { Waga } \\
\text { w \% }\end{array}$ & $\begin{array}{c}\text { Średnia } \\
\text { ocena } \\
\text { w pkt }\end{array}$ & $\begin{array}{c}\text { Sumaryczna } \\
\text { ocena w \% }\end{array}$ & $\begin{array}{c}\text { Waga } \\
\text { w \% }\end{array}$ \\
\hline 1 & $\begin{array}{l}\text { Infrastruktura informacyjno- } \\
\text {-telekomunikacyjna }\end{array}$ & 2,70 & 17,25 & 54,00 & 3,73 & 20,98 & 74,69 \\
\hline 2 & Rynek kapitałowy & 2,35 & 7,51 & 47,00 & 3,97 & 11,15 & 79,38 \\
\hline 3 & Instytucje wsparcia biznesu & 2,50 & 7,99 & 50,00 & 3,56 & 10,01 & 71,25 \\
\hline 4 & $\begin{array}{l}\text { Baza akademicka, } \\
\text { szkolnictwa zawodowego } \\
\text { i jednostek badawczo- } \\
\text {-rozwojowych }\end{array}$ & 2,52 & 10,06 & 50,40 & 3,25 & 11,41 & 65,00 \\
\hline 5 & Klimat gospodarczy & 4,51 & 32,43 & 90,22 & 3,96 & 25,02 & 79,17 \\
\hline 6 & $\begin{array}{l}\text { Tradycje historyczno- } \\
\text {-kulturowe }\end{array}$ & 3,40 & 8,15 & 68,00 & 4,04 & 8,52 & 80,83 \\
\hline 7 & Poziom i jakość życia & 4,16 & 16,61 & 83,20 & 3,68 & 12,91 & 73,50 \\
\hline
\end{tabular}

Źródło: opracowanie własne w oparciu o wyniki badań kwestionariuszowych 


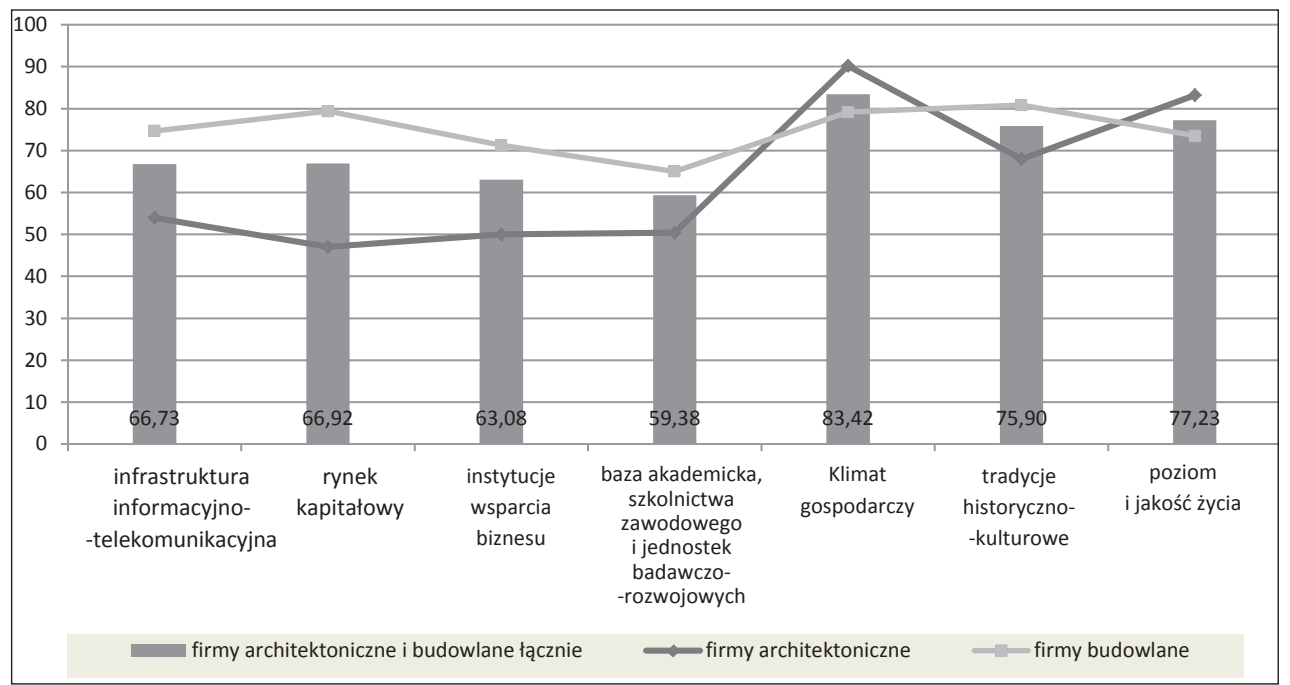

Ryc. 3. Profile lokalizacyjne dla firm architektonicznych i budowlanych wg grup nowoczesnych czynników lokalizacji i ich wag

Źródło: opracowanie własne w oparciu o wyniki badań kwestionariuszowych

Zperspektywy firm architektonicznych zdecydowanie najistotniejsze okazały się trzy grupy czynników: klimat gospodarczy (90\%), poziom i jakość życia (83\%) oraz tradycje historyczno-kulturowe (68\%). Pozostałe cztery czynniki w ocenie respondentów były mniej istotne i uplasowały się na podobnym poziomie: infrastruktura informacyjno-telekomunikacyjna (54\%), baza akademicka, szkolnictwa zawodowego i jednostek badawczo-rozwojowych $(50 \%)$, instytucje wsparcia biznesu (50\%) i rynek kapitałowy (47\%).

$\mathrm{W}$ ocenie respondentów z firm budowlanych różnice istotności poszczególnych grup czynników okazały się mniejsze niż w przypadku ocen dotyczących firm architektonicznych. Dla firm budowlanych najistotniejsze były trzy grupy czynników: tradycje historyczno-kulturowe (81\%), rynek kapitałowy (79\%), klimat gospodarczy (79\%). Pozostałe cztery grupy czynników uznano za nieco mniej istotne: infrastruktura informacyjno-telekomunikacyjna (75\%), poziom i jakość życia (74\%), instytucje wsparcia biznesu (71\%), baza akademicka szkolnictwa zawodowego i jednostek badawczo-rozwojowych (65\%).

Należy zaznaczyć, iż przedsiębiorcy reprezentujący firmy budowlane generalnie byli bardziej skłonni do nadawania nowoczesnym czynnikom lokalizacji większego znaczenia niż przedsiębiorcy reprezentujący firmy architektoniczne. Średnia ocena istotności wszystkich nowoczesnych czynników lokalizacji przedsiębiorstw wystawiona z perspektywy firm budowlanych wyniosła 3,75 , podczas gdy z perspektywy firm architektonicznych była niższa i wyniosła 3,29. Tylko w odniesieniu do dwóch grup czynników: klimat gospodarczy i poziom i jakość życia ocena z perspektywy firm budowlanych była niższa, choć także znacząca, 
niż z perspektywy firm architektonicznych. Dla architektów, jako przedsiębiorców, ale też pracowników, odpowiednio wysoki poziom i jakość życia są istotne z własnego punktu widzenia, ale też z punktu widzenia potencjalnych inwestorów, dla których wykonywane są projekty architektoniczne. Również klimat gospodarczy, a więc m.in. przejrzyste, szybko realizowane procedury administracyjne i wykwalifikowani urzędnicy oraz pozytywne nastawienie władz względem inwestorów, jest niezwykle istotny pod względem funkcjonowania firmy, jak też przyciągania nowych inwestorów, będących źródłem kolejnych zleceń projektowych.

Obok klimatu gospodarczego oraz poziomu i jakości życia, z perspektywy obu rodzajów firm relatywnie wysoko oceniono znaczenie tradycji historyczno-kulturowych, które w branży budowlanej są ważne, gdyż tworzą ogólny klimat sprzyjający atmosferze przedsięwzięć budowlanych, przyciągający nowych inwestorów oraz zapewniający związaną z tą branżą siłę roboczą. Stąd wśród przedstawicieli firm budowlanych ocena tej grupy czynników była wyższa niż wśród przedstawicieli firm architektonicznych. Podobnie jak w odniesieniu do grupy czynników baza akademicka, szkolnictwa zawodowego i jednostek badawczo-rozwojowych, które właściciele firm budowlanych ocenili wyżej niż właściciele pracowni projektowych, kierując się zapewne znaczeniem występowania szkół zawodowych, kształcących wykwalifikowanych pracowników budowlanych, których udział w skali całego kraju wśród ogólnej liczby pracowników budowlanych jest niski, ze względu na systemową w ostatnich latach likwidację zasadniczych i średnich szkół zawodowych. Jak podkreślali respondenci, aktualnie na rynku pracy brakuje wykwalifikowanych pracowników branżowych, zwłaszcza hydraulików i specjalistów prac wykończeniowych.

Największa różnica w ocenie między firmami budowlanymi a architektonicznymi dotyczyła grupy czynników rynek kapitałowy. Okazuje się, że jest to aspekt niezwykle ważny dla firm budowlanych, potrzebujących więcej kapitału niż pracownie architektoniczne. Firmy budowlane są zdecydowanie bardziej kapitałochłonne, głównie z powodu inwestowania w pracowników i sprzęt budowlany, na których opiera się działalność firm oferujących usługi budowlane - wykonawcze i remontowe.

Reasumując, stwierdzić należy, iż przedstawiciele wszystkich badanych firm uznali większość nowoczesnych czynników lokalizacyjnych za istotne. Najważniejsze okazały się czynniki dotyczące klimatu gospodarczego, zarówno w ocenie ogólnej czynników bazowych, jak też na podstawie oceny czynników cząstkowych. Ocena ogólna czynników bazowych odbiegała nieco od późniejszej oceny dokonanej według czynników cząstkowych, jednakże w ogólnym zarysie pozostała podtrzymana. Obok klimatu gospodarczego, w obu przypadkach wysokie oceny dotyczyły infrastruktury informacyjno-telekomunikacyjnej oraz poziomu i jakości życia. Należy zaznaczyć, iż omawiane nowoczesne czynniki lokalizacyjne dla firm budowlanych okazały się nieco istotniejsze niż dla firm architektonicznych, dotyczyło to zwłaszcza grupy czynników rynku kapitałowego. 


\section{PERSONALNY CZYNNIK DECYZJI LOKALIZACYJNYCH PRZEDSIĘBIORSTWA - STUDIUM PRZYPADKU}

W ramach badań zostały przeprowadzone wywiady pogłębione z właścicielami 2 firm: architektonicznej i budowlanej. W niniejszym artykule zaprezentowano skrócone wyniki jednego z wywiadów dotyczącego motywów osobistych lokalizacji firmy architektonicznej. Pełniejsze omówienie obu wywiadów pogłębionych wraz z analizą porównawczą istotności czynników klasycznych i nowoczesnych w decyzjach lokalizacyjnych przedsiębiorstw znalazło miejsce w osobnym opracowaniu (Płaziak, Szymańska, 2014).

Badana firma należy do kategorii mikroprzedsiębiorstw i zatrudnia sześć osób, wykonujących prace z zakresu projektowania architektonicznego zarówno dla odbiorcy prywatnego, jak też przedsiębiorców oraz podmiotów państwowych i samorządowych. Siedziba firmy została zlokalizowana na terenie Krakowa, jednakże jej działalność nie dotyczy wyłącznie miasta, lecz obejmuje całe województwo, a nawet inne regiony kraju, a sporadycznie wykracza poza granice Polski. Dwóch współwłaścicieli firmy dokonało oceny motywów lokalizacji aktualnej siedziby firmy. Przy czym, w ciągu 14 lat działalności firmy obecna siedziba jest czwartą z rzędu.

Wszystkie dotychczasowe siedziby analizowanej firmy zlokalizowane były w Krakowie. Właściciele nigdy nie brali pod uwagę innej lokalizacji, co świadczy o bardzo personalnym podejściu do problemu lokalizacji działalności gospodarczej. Z wywiadu wynika, iż obaj właściciele zdobyli wysoki poziom percepcji Krakowa i znają jego uwarunkowania gospodarcze bardzo dobrze, z racji wieloletniego zamieszkiwania i studiowania tam. W wywiadzie zostało podkreślonych wiele atutów lokalizacji działalności właśnie w tym mieście, które wskazywały bezpośrednio na zewnętrzne korzyści aglomeracji. Bliskość dużego rynku zbytu w postaci potencjalnych odbiorców projektów, a także wykwalifikowanej kadry inżynierskiej i firm prowadzących działalność z branż pokrewnych (firmy świadczące usługi budowlane, biura projektowe branżowe, np. konstruktorskie) oraz urzędów, wymienione zostały jako najistotniejsze.

Kolejne relokacje firmy zawsze związane były z jej rozwojem i potrzebą poprawy warunków pracy, a także polepszeniem wizerunku i rozwojem marki. Jak przyznali właściciele, przy wyborze każdej z siedzib kierowali się wysokością kosztów wynajmu, jednakże nie był to czynnik dominujący. Każda z następnych siedzib była droższa i w procesie decyzyjnym wyboru lokalizacji przeważał czynnik wygody i prestiżu nad kosztami. Ponadto, jak stwierdzili respondenci, przy wyborze ostatnich dwóch lokalizacji kierowano się nie tyle dogłębną analizą kosztową, a raczej wykorzystano wcześniej zdobytą wiedzę dotyczącą możliwych do zajęcia pustych lokali. Jak podkreślają respondenci, planują kolejną relokację firmy. Tym razem powodem okazują się być czynniki finansowe, związane z relatywnie wysokim kosztem najmu lokalu. Pod uwagę brana jest lokalizacja nawet poza Krakowem, jednakże w pobliżu miasta. Niewykluczone, iż przy wyborze zadecyduje ponownie czynnik personalny, gdyż właściciele firmy skłonni są ulokować jej siedzibę w pobliżu aktualnego miejsca zamieszkania, jakim jest podkrakowska gmina.

Zaprezentowany tutaj przykład motywów lokalizacyjnych niewielkiej firmy dowodzi, iż czynniki tzw. „miękkie” i personalne mogą, obok „twardych”, czyli najczęściej kosztowych, 
mieć spore znaczenie, czasami decydujące. W omawianym przypadku decyzja lokalizacyjna oczywiście wymagała podstawowej analizy dotyczącej możliwości finansowych firmy, dostępności dla klienta (dobre skomunikowanie, miejsca parkingowe), bliskości rynków zbytu, a więc tzw. czynników „twardych”. Jednakże można uznać, iż na ostatecznej decyzji zaważyły czynniki „miękkie”, zwłaszcza dotyczące prestiżu firmy, oraz aspekty personalne. Z pewnością udział czynnika osobowego w tego rodzaju decyzjach jest zróżnicowany z wielu powodów, należy się spodziewać, iż jego znaczenie maleje wraz ze wzrostem wielkości przedsiębiorstwa.

\section{ZAKOŃCZENIE}

Na decyzję dotyczącą lokalizacji działalności gospodarczej wpływa wiele zmiennych. Wraz z postępem gospodarczym i rozwojem społecznym obok typowych czynników kosztowych pojawia się coraz więcej czynników jakościowych. Z całą pewnością nie można klasycznych czynników lokalizacyjnych deprecjonować. Niektóre z nich, jak chociażby zewnętrzne korzyści aglomeracji, w wielu decyzjach lokalizacyjnych mają znaczenie kluczowe. Jednakże udział niektórych czynników kosztowych, dawniej bardzo istotnych, maleje. Na skutek rozwoju transportu, miniaturyzacji i konteneryzacji obniżają się koszty związane z przewozem lub uzyskaniem surowców, a komputeryzacja i mechanizacja pracy osłabiła znaczenie czynnika dostępu do taniej siły roboczej. Jednocześnie szybkie tempo rozwoju i rosnące potrzeby ludzkie, zarówno odbiorców produktów i usług, jak też przedsiębiorców i pracowników, generują nowe czynniki brane pod uwagę w decyzjach lokalizacyjnych przedsiębiorstw. W literaturze przedmiotu do nowoczesnych czynników lokalizacyjnych zalicza się przede wszystkim: jakość kapitału ludzkiego, kapitał społeczny, dostęp do informacji i jej użyteczność, kapitał wiedzy i kreatywności, dostęp do usług biznesowych oraz poziom i jakość życia w regionie.

W opracowaniu dokonano potwierdzenia istotności nowoczesnych czynników lokalizacji z perspektywy decydentów. W przypadku badanych firm z sektora budowlanego okazało się, że duże znaczenie mają czynniki dotyczące klimatu gospodarczego, infrastruktury informacyjno-telekomunikacyjnej oraz poziomu i jakości życia. Przy czym wykazano, iż ważność poszczególnych czynników zależy od rodzaju działalności. Z perspektywy firm architektonicznych zdecydowanie najistotniejsze okazały się czynniki dotyczące klimatu gospodarczego, poziomu i jakości życia oraz tradycji historyczno-kulturowych. Natomiast dla firm budowlanych najważniejsze były tradycje historyczno-kulturowe, rynek kapitałowy i klimat gospodarczy.

Na ostateczny wybór miejsca działalności gospodarczej, obok szeregu czynników wynikających z wymagań inwestycyjnych i walorów klimatu inwestycyjnego miejsca, wpływ mają decyzje personalne. Nie można abstrahować od udziału cech (zdolności i ograniczeń) oraz motywów i zamierzeń decydenta w procesie decyzyjnym. Zgodnie z podejściem behawioralnym do problematyki, czynnik ludzki w postępowaniu decyzyjnym kierunkuje wybór lokalizacji nie w miejsce optymalne, lecz zadowalające. 


\section{Literatura \\ References}

Budner, W. (2003). Lokalizacja przedsiębiorstw. Aspekty ekonomiczno-przestrzenne i środowiskowe. Poznań: Wydawnictwo Akademii Ekonomicznej w Poznaniu.

Domański, R. (2011). Gospodarka przestrzenna. Podstawy teoretyczne. Warszawa: Wydawnictwo Naukowe PWN.

Dziemianowicz, W. (1997). Kapitał zagraniczny a rozwój regionalny i lokalny w Polsce. Studia Regionalne i Lokalne, 21 (54). Warszawa: Europejski Instytut Rozwoju Regionalnego i Lokalnego UW.

Dziemianowicz, W. (1998). Rola władz samorządowych w stymulowaniu napływu bezpośrednich inwestycji zagranicznych. W: Z. Olesiński (red.). Bezpośrednie inwestycje zagraniczne. Warszawa: PWE.

Fabińska, M., Piasecki T. (2007). Benchmarking regionalny. Łódź: Społeczna Wyższa Szkoła Przedsiębiorczości i Zarządzania w Łodzi.

Fierla, I. (1987). Lokalizacja przemystu. Warszawa: PWE.

Fierla, I. (1998). Lokalizacja przedsiębiorstw: wybrane zagadnienia. Ostrowiec Świętokrzyski: Stowarzyszenie na Rzecz Rozwoju WSBiP.

Hoover, E.M. (1948). The Location of Economic Activity. New York: McGraw-Hill.

Isard, W. (1956). Location and Space-economy. New York: J. Wiley and Sons.

Karlsson, Ch., Johansson, B., Stough, R.R. (2005). Industrial Clusters and Inter-firm Networks: An Introduction. W: Ch. Karlsson, B. Johansson, R.R. Stough (red.). Industrial Clusters and Inter-firm Networks. Cheltenham, Northampton: Edward Elgar Publishing.

Krugman, P. (1991). Geography and Trade. Cambridge: MIT Press.

Lösch, A. (1940). Die räumliche Ordnung der Wirtschaft. Jena: Gustav Fischer.

Marshall, A. (1932). Elements of Economics. London: MacMillan.

McCann, P. (2001). Urban and Regional Economics. Oxford: Oxford University Press.

Ohlin, B.G. (1933). Inter-regional and International Trade. Harvard: Harvard University Press.

Płaziak, M., Szymańska, A.I. (2014). Importance of personal factor in decisions on locating enterprises. Procedia - Social and Behavioral Sciences, 110, 373-380.

Pred, A.R. (1967). Behaviour and Location: Foundations for a Geographic Dynamic Location Theory. Part 1. Lund 1967, Studies in Geography. Series B. 27.

Rachwał, T. (2012). Innowacyjność przedsiębiorstw przemysłowych jako czynnik rozwoju miast. Studia Komitetu Przestrzennego Zagospodarowania Kraju PAN. 141, 135-152.

Szymańska, A.I., Płaziak, M. (2014). Factors considered in location of construction enterprises in the Małopolska Region. Procedia - Social and Behavioral Sciences, 110, 381-389.

Tobolska, A. (2011). Czynniki lokalizacji fabryk wybranych korporacji międzynarodowych w Polsce. W: M. Wdowicka, L. Mierzejewska (red.). Problemy rozwoju lokalnego i regionalnego na początku XXI wieku. Biuletyn Instytutu Geografii Spoteczno-Ekonomicznej i Gospodarki Przestrzennej UAM. Seria Rozwój Regionalny i Polityka Regionalna, 15, Poznań: Bogucki Wydawnictwo Naukowe.

Törnqvist, G.E. (1977). The Geography of Economic Activities: Some Critical Viewpoints on Theory and Application. Economic Geography, 53, 153-62.

Wach, K. (2008). Regionalne otoczenie matych i średnich przedsiębiorstw. Kraków: Wydawnictwo Uniwersytetu Ekonomicznego w Krakowie, 67, 45-73.

Walmsley, D.J., Lewis G. (1984). Human Geography: Behavioural Approaches. London: Longman Group.

Wieloński, A. (2004). Lokalizacja działalności gospodarczej. Teoretyczne podstawy. Warszawa: Wydawnictwo Uniwersytetu Warszawskiego. 
Monika Płaziak, dr, Uniwersytet Pedagogiczny, Instytut Geografii, Zakład Przedsiębiorczości i Gospodarki Przestrzennej.

Adiunkt w Zakładzie Przedsiębiorczości i Gospodarki Przestrzennej, Instytut Geografii, Uniwersytet Pedagogiczny w Krakowie. Studia magisterskie i doktoranckie ukończyła w Instytucie Geografii i Gospodarki Przestrzennej Uniwersytetu Jagiellońskiego. Zainteresowania badawcze autorki dotyczą zagadnień gospodarki przestrzennej w kontekście zrównoważonego rozwoju - miast zrównoważonych społecznie i miast energooszczędnych, a także lokalizacji przedsiębiorstw, zwłaszcza przemysłowych i budowlanych. Prace badawcze odnoszą się również do zagadnień współpracy jednostek naukowych i badawczo-rozwojowych z sektorem MŚP, głównie w zakresie wdrażania nowych technologii i materiałów, w tym dotyczących budownictwa energooszczędnego i pasywnego. Ponadto autorka zajmuje się problematyką poziomu i jakości życia ludności, ze szczególnym uwzględnieniem małych i średnich miast Polski.

Monika Plaziak, Ph.D. is an assistant professor in the Department of Entrepreneurship and Spatial Management, Institute of Geography, the Pedagogical University of Cracow. She graduated from the Jagiellonian University in Krakow and got her PhD degree in economic geography (at the Jagiellonian University in Krakow), Research interests of the author concern issues of spatial development in the context of sustainable development - socially balanced towns and energy-efficient towns, and also the locating of industrial and construction enterprises. Additionally, her research works include the cooperation of scientific and R\&D organizations with the SME sector, especially in the area of implementing new technologies and materials concerning the energy-efficient and passive building. Moreover, the author analyses issues of the level and quality of life, with particular focus on small and medium-sized towns in Poland.

Anna Irena Szymańska, dr, Uniwersytet Pedagogiczny, Instytut Geografii, Zakład Przedsiębiorczości i Gospodarki Przestrzennej.

Absolwentka studiów z zakresu zarządzania i marketingu Uniwersytetu Ekonomicznego w Krakowie, doktor nauk ekonomicznych w zakresie nauk o zarządzaniu (Katedra Analizy Rynku i Badań Rynkowych - Uniwersytet Ekonomiczny w Krakowie). Adiunkt w Zakładzie Przedsiębiorczości i Gospodarki Przestrzennej Uniwersytetu Pedagogicznego w Krakowie. Zainteresowania badawcze oscylują wokół problematyki potrzeb, preferencji i zachowań rynkowych konsumentów, jak również zagadnień z obszaru przedsiębiorczości i innowacyjności przedsiębiorstw ze szczególnym uwzględnieniem sektora MŚP.

Anna Irena Szymańska, Ph.D. graduated from the Cracow University of Economics, holds an MA degree in Management and Marketing and a PhD degree in Economic Sciences in the field of Management Sciences (Chair of Market Analysis and Marketing Research - the Cracow University of Economics). She is an assistant professor in the Department of Entrepreneurship and Spatial Management at the Pedagogical University of Crakow. Her research interests are related to the issue of consumer needs, preferences and market behaviour, as well the area of entrepreneurship and innovation, with particular emphasis on the SME sector.

\section{Adres/address:}

Uniwersytet Pedagogiczny

Instytut Geografii

Zakład Przedsiębiorczości i Gospodarki Przestrzennej

ul. Podchorążych 2, 30-084 Kraków, Polska

e-mail:mplaziak@up.krakow.pl

e-mail: aszym@up.krakow.pl 